\title{
Railway supply chain excellence through the mediator role of business intelligence: Knowledge management approach towards information system
}

\author{
Mailasan Jayakrishnan $^{a^{*}}$, Abdul Karim Mohamad ${ }^{a}$ and Mokhtar Mohd Yusof ${ }^{b}$
}

${ }^{a}$ Centre for Advanced Computing Technology, Faculty of Information \& Communication Technology, Universiti Teknikal Malaysia Melaka, Malaysia ${ }^{b}$ Faculty of Computer and Information Technology, Al-Madinah International University, Malaysia

\section{A B S T R A C T}

Article history:

Received June 18, 2021

Received in revised format July

20, 2021

Accepted October 22021

Available online

October 32021

Keywords:

Business Intelligence

Knowledge Management

Railway Supply Chain

Information System

Supplier Performance

\begin{abstract}
The features of a holistic view in an organization create the data value of the Business Intelligence (BI) and Knowledge Management (KM) in viewing the big picture of organizational performance diagnostics framework. This research focuses on the specific features of railway supply chain performance in viewing the decision-making process and creating better knowledge formation. The intention of the study is to structure supplier performance using BI-KM framework development to determine holistic perspective factors. The outcomes indicate that BI and KM significantly increased the railway supply chain and significantly increased the information system. This BI-KM framework relates the current analytic characteristics in designing the railway supply chain towards information system in determining the strategic theme of the decisionmaking process of the decision support system together with system features, characteristics of data, the content of the themes, and the effect of the decision-making process and for executive strategic performance diagnostics tool that provides effective strategic decision making in supply chain performance. The quantitative research method uses SmartPLS software version 3.2.8 for empirical analysis through distributing survey questionnaires to 320 railway suppliers in Malaysia. Using a model-driven development framework, to measure the implementation success of the decision support system, the study is conducted in the railway supplier focusing on strategic management that helps to make the decision and facilitate the organizational success.
\end{abstract}

(C) 2022 Growing Science Ltd. All rights reserved.

\section{Introduction}

Nowadays, knowledge and information constitute the initial prosperity of a business. The railway supply chain attempts to employ this prosperity to obtain a competitive edge when composing vital decisions (MIGHT, 2018). Business Intelligence (BI) has acquired acknowledgment and Knowledge Management (KM) has combined gathering of complexity bringing as one of the large number and technologies included. These will convert and store the information for utilizing it as a pool of information to assist verdicts and prospect relevant information in railway supply chain management (Jayakrishnan, Mohamad, \& Yusof, 2021). The evaluation of railway supply chain excellence needs a framework and perspective that contemplates insight standards, as the conventional function and non-practical specification and principle. The research was undertaken to assess the railway suppliers on their strategic planning process and utilizing indicators for better decisionmaking in analyzing and solving real organizational problems innovatively. Furthermore, it seems that the railway supply chain is ill-formulating the necessity and desire of suppliers in the market to transfer the proper knowledge efficiently and effectively (Petrillo, Felice, Cioffi, \& Zomparelli, 2018; Chourides et al., 2003). The fact that the railway supplier appears to reveal an understanding of this possible complication is encouraged. We believe that KM is finally viable, and BI plays a significant part in the decision-making process for running day-to-day supplier tasks and store data to assist suppliers to

* Corresponding author

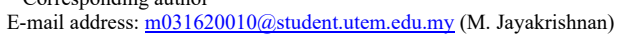

(c) 2022 Growing Science Ltd. All rights reserved.

doi: $10.5267 /$ j.uscm.2021.10.003 
comprehend, improve, and enhance their performance. This data structure can be analyzed and reported directly with an integrated KM and BI, as shown in Fig. 1.

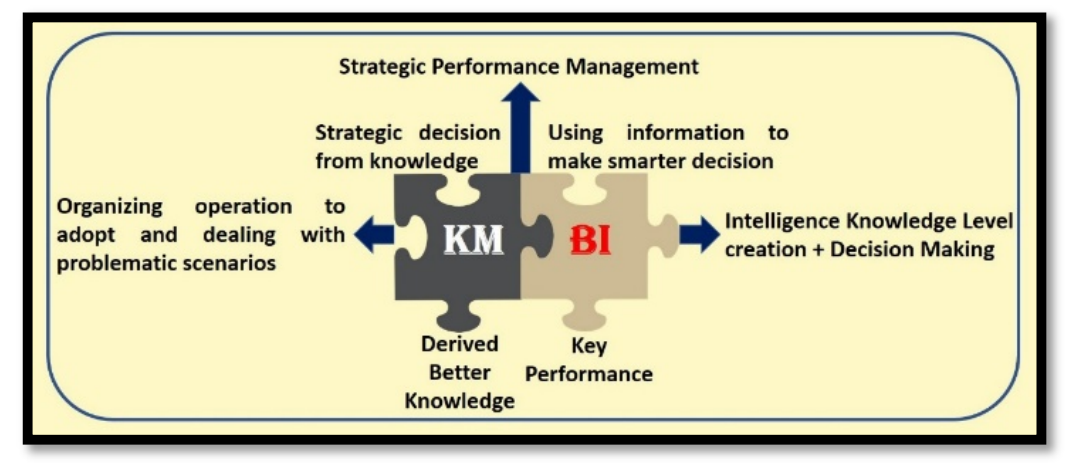

Fig. 1. The Integrated KM and BI Approach.

Based on Fig. 1, the integrated KM and BI approach is to stimulate factors of strategic performance diagnostics modeling tools. A recent systematic literature review dissolves that there is no comprehensive record of specification for this KM and BI analysis. Previous research encountered minimal awareness to perception basis and did not invent frameworks to analyse these indicators especially in the railway supply chain (Odolinski, K. and Boysen, 2019). Our present case study focuses on the railway supply chain in the insight of organizational excellence. An empirical review has been carried out for a new and greater methodology in information system decision making towards tending the data silo and sharing data between the supply chain performance for improving the decision-making process. From the literature review and specific analysis, the case study determines the mediator factors of BI and KM by designing and developing a conceptual model. Moreover, we have examined how far a strategic performance indicator enhances a supplier's KPI in BI-KM mediator effects. To discover those criteria, a systematic literature review related to supply chain management for performance diagnostics models in organization learning especially the adoption of holistic approaches among railway suppliers is conducted. A conceptual model has been developed to evaluate their practical and non-useful classification to analyze and designate information for their decision-making activity needs. The supply chain action is one of the essential reasons for stakeholders or decisionmakers to utilize the system (Jayakrishnan, Mohamad, \& Yusof, 2020c). The findings yield that strategic decision-making on its supplier KPIs leads towards the achievement and success of the railway supply chain. Furthermore, we have examined the strongest mediator factors of BI and KM. In the future, the important scientific goal in strategic decision-making design fully addresses the demands and requirements of information systems in a working environment. Without effective strategic decision-making diagnostic design, it may affect the decision-makers or stakeholders in executing their tasks efficiently.

\section{Literature review}

The case study has identified the holistic perspective in captivating the mediator factor of BI and KM in organization learning to adopt strategic decision-making tasks. The literature reveals that BI is emphatically identified with the strategic process (Jayakrishnan, Mohamad, \& Yusof, 2020b) and KM embraces strategic dynamic to view each stage of the supply chain management process with their supplier KPI's (Santis, Golliat, \& Aguiar, 2017). The railway supply chain will have higher intentions to adopt the strategic diagnostic tool to guarantee the dynamic on KPIs achieved. Concerning BI and KM, supply chain choices are at the functional stage in an organization, and unstructured choices for stakeholders to yield assessment, judgment, and knowledge into the issues for the most persuasive factor (Emery \& Morton, 1972; Ming, Teng, \& Jodaki, 2020). The literature indicates that BI and KM are emphatically interconnected to the supply chain functions of the strategic dynamic cycle (Jayakrishnan, Mohamad, \& Yusof, 2020a). The information and knowledge will have higher goals to embrace BI and KM because it energizes organizational learning in an information system (Odolinski, K. and Boysen, 2019). It is also the key to success for railway supply chain decision-making implementation (Cagnin, Oliveira, Simon, Helleno, \& Vendramini, 2016). The literature shows that dynamic in the essential supply chain management operation is identified to the reception of intelligence and knowledge process to all the essential management activities. BI context and process are key to lead strategic decision-making to adopt supplier KPI's (Safa, Shahi, Haas, \& Hipel, 2014). The case study contributes to the influence of various characteristics such as technology, strategy, environment, structure especially information system and philosophy on organizational learning. The literature also shows that the impact of organizational learning on supplier performance is identified to the shared value of vital management, strategic insight, and supply chain performance. The railway supply chain will encounter planned KPI's in their organization through strategic decision-making and diagnostic tool adoption. The outcome of the current case research has few pertinent commitments towards the railway supply chain. BI as a mechanism of evaluation, providing automated decision-making through reporting, planning, and utilizing knowledge from multiple genes and soliciting the previous incident to prosper and impose assimilation of supply chain dynamics (Jayakrishnan, Mohamad, \& Yusof, 2020d). It combines the scrutiny of information with the conclusion-inspection platform to yield the proper knowledge to the precise decision-makers throughout the supply chain management, with the aspiration of enhancing tactical and strategic decisions. The mediator 
role of $\mathrm{BI}$ and $\mathrm{KM}$ as the technical and managerial perspective for railway supply chain excellence is shown in Fig. 2 and Fig. 3.

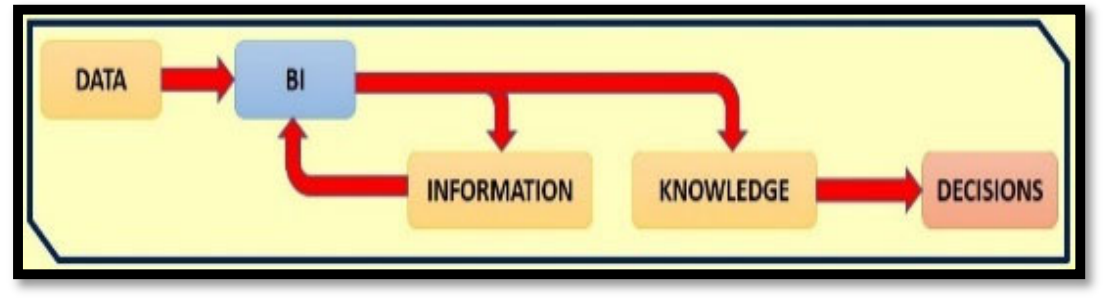

Fig. 2. The Mediator Flow Perspective of BI

BI utilizes data to produce information that can be solicited to trigger knowledge and this knowledge is prospering as explicit knowledge. Managerial Perspective-BI as an action in which knowledge converges from inside and outside of the railway supply chain is coherent in structure to foster data proper to the decision-making activity.

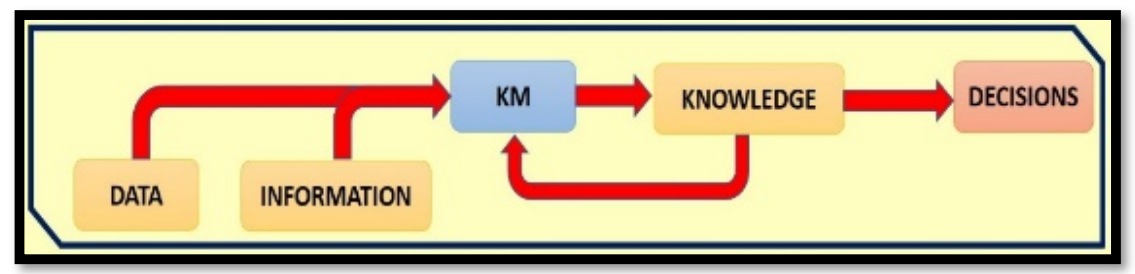

Fig. 3. The Mediator Flow Perspective of KM

KM utilizes both information and data to prosper knowledge and this knowledge is more expanding to generate advanced knowledge as tacit and explicit knowledge. Technical Perspective-KM's focus is to build an informational surrounding in which functional information converges and external genesis can be scrutinized in structure to extract strategic organization knowledge to assist the unstructured decisions of railway supply chain management. Based on Fig. 2 and Fig. 3, the mediator role of BI and KM for the railway supply chain can be indicated as BI application in knowledge capture or creation of activities. This means that we apply BI applications in a railway supply chain for capturing and creating information leading to knowledge in tacit and explicit knowledge. The cognate knowledge and information of a railway supply chain will chronicle the surroundings and the knowledge for composition decisions. In the context of organizational learning, holistic view in the appealing factor of BI and KM perspective on supply chain aspect is the most influential factor determining the adoption of the strategic decision-making process. To adopt a strategic diagnostic tool, organization learning must embody railway supply chain culture to ensure the BI and KM perspective on the information system dimension of the strategic KPI's of the railway supply chain. Moreover, the mediator role of BI and KM is the symposium of intelligence to bear the strategic decision-making action and to execute the railway supply chain goals, mission, and vision towards improving the performance. Furthermore, providing an approach to the information system to assist railway supply chain management in creating dynamic decisions, that contain advanced decisions on a daily basis.

\section{Methodology}

The significance of the approach to diagnosing supply chain management is highlighted and discussed. (Martin, Rooksby, Rouncefield, \& Sommerville, 2007) indicates that it is one of the strides in the analysis procedure where it assists to initiate the flow for researchers to go around accomplishing their analysis aims. It is also a systematic element of analysis in the ideology, perspective, quality of information, policy, time horizons, and procedures and techniques (Saunders, Lewis, \& Thornhill, 2009). This will eventually determine the model and framework used for implementation. According to (Sousa, 2010), the philosophy of Information System (IS) research deals along with the generalized explanation of the component and hinges on the organization's methodologies. IS research has prevailed multi-cultural and multi-perspective in providing varied content to ideally interpret the organization approaches (Halvorson, 2012). The dimension of the current world view of philosophy comprises the postpositive method, interpretive method, critical approach, and postmodern method as shown in Table 1. Based on Table 1, our organizational methodology world views today, where the element of this research is positivism whereby the research forms scenarios that can be tried. The component of the methodology contains inductive and deductive (Comuzzi \& Parhizkar, 2017). This research applied a deductive methodology whereby it got questions from speculations, reviewing the extant literature, and getting an affirmation of the question. A review technique was applied for this research because it is normally related to a deductive methodology. Moreover, these strategic planning scenarios can be implemented from a philosophical view derived according to the strategic research paradigm in an organization as presented in Table 2. 
Table 1

Our Organizational Methodology World Views Today.

\begin{tabular}{|c|c|c|c|c|}
\hline \multirow{2}{*}{ Approaches } & \multicolumn{3}{|c|}{ Paradigm } & \multirow{2}{*}{ Organizational Views } \\
\hline & Ontology & Epistemology & Methodology & \\
\hline $\begin{array}{l}\text { Postpositive Approach } \\
\text { Positivism-(Quantitative) holds } \\
\text { that an administration has an } \\
\text { objective situation; mankind goes } \\
\text { and comes, but the organization } \\
\text { suffers. }\end{array}$ & $\begin{array}{l}\text { There is an impartial } \\
\text { actuality, and we can } \\
\text { understand and it via } \\
\text { the regulation by } \\
\text { which it is regulated. }\end{array}$ & $\begin{array}{l}\text { Engage a systematic } \\
\text { communication to obtain from } \\
\text { the epistemologies of realism } \\
\text { and positivism }\end{array}$ & Deduction, Experimental & $\begin{array}{l}\text { An organization has an } \\
\text { objective existence. }\end{array}$ \\
\hline $\begin{array}{l}\text { The Interpretive Approach } \\
\text { (Qualitative) embrace that an } \\
\text { administration has a subjective } \\
\text { situation; mankind creates and } \\
\text { assists it via their communication. }\end{array}$ & $\begin{array}{l}\text { Globe and perception } \\
\text { generated by the } \\
\text { community } \\
\text { contextual and } \\
\text { assimilation. }\end{array}$ & $\begin{array}{l}\text { How do we approach } \\
\text { assimilation a } \quad \text { special } \\
\text { workforce's worldview }\end{array}$ & $\begin{array}{l}\text { Qualitative mechanism- } \\
\text { phenomenology, } \\
\text { interviews, narrative, } \\
\text { case study observations, } \\
\text { and ethnography }\end{array}$ & $\begin{array}{l}\text { An organization has a } \\
\text { subjective existence. }\end{array}$ \\
\hline $\begin{array}{l}\text { The Critical Approach } \\
\text { (Quantitative and Qualitative) } \\
\text { holds the structures of power } \\
\text { within an organization have a } \\
\text { permanent existence and reflect } \\
\text { enormous historical and cultural } \\
\text { intensity. }\end{array}$ & $\begin{array}{l}\text { Actuality subsist and } \\
\text { possess } \quad \text { betide } \\
\text { generate by governing } \\
\text { community diagonal }\end{array}$ & $\begin{array}{l}\text { Assimilation persecute } \\
\text { perspective by unveiling the } \\
\text { opposed states of activity which } \\
\text { are covered up or twisted by } \\
\text { ordinary arrangement and work } \\
\text { to assist change social } \\
\text { conditions }\end{array}$ & $\begin{array}{l}\text { The critical investigation, } \\
\text { historic audit, and take an } \\
\text { interest in programs of } \\
\text { activity }\end{array}$ & $\begin{array}{l}\text { The formation of } \\
\text { power inside an } \\
\text { organization has a } \\
\text { fixed existence, } \\
\text { cultural forces, and } \\
\text { historical. }\end{array}$ \\
\hline $\begin{array}{l}\text { The Postmodern Approach (Mixed } \\
\text { Mode) equally embraces the power } \\
\text { interconnection within an } \\
\text { organization indicate cultural } \\
\text { discourses and larger historical, but } \\
\text { these discourses are ever-changing } \\
\text { and fluid. }\end{array}$ & $\begin{array}{l}\text { Actuality is the } \\
\text { empirical outcome of a } \\
\text { proposition. }\end{array}$ & $\begin{array}{l}\text { Any technique of analytical or } \\
\text { execution that usher to the } \\
\text { pragmatic infusion is practical. }\end{array}$ & $\begin{array}{l}\text { Mixed technique, action } \\
\text { research, and design- } \\
\text { based research. }\end{array}$ & $\begin{array}{l}\text { The competence } \\
\text { interconnection within } \\
\text { an organization } \\
\text { reflects larger } \\
\text { historical and cultural } \\
\text { discourses. }\end{array}$ \\
\hline
\end{tabular}

Table 2

The Strategic Research Paradigm of IS in Organization

\begin{tabular}{|c|c|c|c|}
\hline Assumption & $\begin{array}{c}\text { Positivism } \\
\text { (Operational) }\end{array}$ & $\begin{array}{c}\text { Interpretivism } \\
\text { (Tactical) }\end{array}$ & $\begin{array}{l}\text { Critical realism } \\
\text { (Strategic) }\end{array}$ \\
\hline $\begin{array}{l}\text { Ontology: The position on the } \\
\text { nature of reality }\end{array}$ & $\begin{array}{l}\text { Secret standards oversee the } \\
\text { instructing and learning measure- } \\
\text { External, objective, and } \\
\text { independent. } \\
\text { (Process Efficiency) }\end{array}$ & $\begin{array}{l}\text { The standards are made by people in } \\
\text { groups-Socially constructed, } \\
\text { subjective, may change, and } \\
\text { multiple. } \\
\text { (Enlightenment) }\end{array}$ & $\begin{array}{l}\text { Society is overflowing with } \\
\text { disparities and injustice-Exist } \\
\text { independently of human thoughts } \\
\text { and knowledge. } \\
\text { (Organizational Effectiveness) }\end{array}$ \\
\hline $\begin{array}{l}\text { Epistemology: The perspective } \\
\text { on what comprises acceptable } \\
\text { knowledge }\end{array}$ & $\begin{array}{l}\text { Pivot on the dependable and } \\
\text { logical appliance to the } \\
\text { confidential ordinance-Only } \\
\text { observable situation can present } \\
\text { credible facts and data. Emphasis } \\
\text { on law-like generalizations and } \\
\text { causality, reducing the situation to } \\
\text { simplest components. }\end{array}$ & $\begin{array}{l}\text { Locate the repressed definition of } \\
\text { the incident and ventures-Subjective } \\
\text { meanings and analysis phenomena. } \\
\text { Emphasis upon the factor of the } \\
\text { incident, subjective meanings, } \\
\text { motivating actions, and the reality } \\
\text { behind these components. }\end{array}$ & $\begin{array}{l}\text { Helping uncover injustice and } \\
\text { empowering citizens-Only evident } \\
\text { situations can furnish credible } \\
\text { features and data. Emphasis on } \\
\text { interpreting within a situation. }\end{array}$ \\
\hline $\begin{array}{l}\text { Methodology: The design urging } \\
\text { the research approach }\end{array}$ & $\begin{array}{l}\text { Quantitative } \\
\text { (Organizational Cybernetics) }\end{array}$ & $\begin{array}{l}\text { Qualitative } \\
\text { (Hard Systems Thinking) }\end{array}$ & $\begin{array}{l}\text { Quantitative or Qualitative (Soft } \\
\text { Systems Thinking) }\end{array}$ \\
\hline Question & What works? & Why do you act this way? & How can I change this situation? \\
\hline Outcome & $\begin{array}{l}\text { Functionality Architecture } \\
\text { (To assist the specific, dependable, } \\
\text { systematic organize of information } \\
\text { and transmission of knowledge) }\end{array}$ & $\begin{array}{l}\text { Systems Capabilities Framework } \\
\text { (To assist the productive use of } \\
\text { knowledge resources and } \\
\text { information) }\end{array}$ & $\begin{array}{l}\text { Data transfer technology } \\
\text { framework } \\
\text { (To engage in organizational } \\
\text { learning, innovation, and } \\
\text { adaptation) }\end{array}$ \\
\hline Culture or Structure & $\begin{array}{l}\text { (Knowledge Infrastructure } \\
\text { Building) }\end{array}$ & (Knowledge Organization) & (Knowledge Creation and Use) \\
\hline
\end{tabular}

Table 2 has summarized the strategic research paradigm of IS in an organization that influences strategic decision-making for positivism paradigm seeks on operation level, the interpretivism paradigm seeks on a tactical level and the critical realism paradigm seeks on the strategic level. The research demonstrates by utilizing a causal study. It is otherwise called an explanatory study where the significant goal of this methodology is to foster a conceptual framework regarding cause and effect relationships (Malhotra, 2007). The causal study design is considered the perfect technique to simulate cause and effect outcomes (Chourides, Longbottom, \& Murphy, 2003). This study is quantitative uses SmartPLS software version 3.2.8 for empirical analysis through distributing survey questionnaires to 320 railway suppliers in Malaysia. Therefore, this study builds the conceptual model to interpret the outcomes in Fig. 4.

\section{Results and discussion}

The study depends on Structural Equation Modelling (SEM) as an analysis method. As a feature of practical data study, the reliability and validity of the quantifying design are trailed by the validity of the structural design. Moreover, the mediator 
role of BI and KM has been measured. The data utilized in this research was gathered from a railway supplier in Malaysia, where 500 questionnaires were distributed and an aggregate of 400 questionnaires was returned, hence resulting in a reaction pace of $80 \%$. Still, out of 400 questionnaires, 22 were discovered to contain an incomplete missing rate of more than $10 \%$ hence eliminated from the data analysis. In addition, 9 questionnaires were set on as having unavailable reactions because of their standard deviation rate of 0 .

Table 3

Data distribution based on Skewness and Kurtosis tests

\begin{tabular}{|c|c|c|c|c|}
\hline Constructs & Missing & Standard Deviation & Excess Kurtosis & Skewness \\
\hline RSC1 & 0 & 1.767 & -1.018 & -0.517 \\
\hline $\mathrm{RSC} 2$ & 0 & 1.739 & -1.345 & -0.096 \\
\hline $\mathrm{RSC} 3$ & 0 & 1.773 & -1.344 & -0.088 \\
\hline RSC4 & 0 & 1.769 & -1.322 & -0.123 \\
\hline RSC5 & 0 & 1.789 & -1.288 & -0.196 \\
\hline RSC6 & 0 & 1.806 & -1.216 & -0.288 \\
\hline RSC7 & 0 & 1.728 & -1.248 & -0.29 \\
\hline RSC8 & 0 & 1.773 & -1.282 & -0.309 \\
\hline RSC9 & 0 & 1.783 & -1.176 & -0.331 \\
\hline RSC10 & 0 & 1.681 & -1.203 & -0.268 \\
\hline RSC11 & 0 & 1.783 & -1.187 & -0.353 \\
\hline RSC12 & 0 & 1.767 & -1.242 & -0.235 \\
\hline $\mathrm{RSC} 13$ & 0 & 1.822 & -1.369 & -0.165 \\
\hline RSC14 & 0 & 1.793 & -1.25 & -0.238 \\
\hline RSC15 & 0 & 1.781 & -1.2 & -0.331 \\
\hline RSC16 & 0 & 1.726 & -1.296 & -0.205 \\
\hline RSC17 & 0 & 1.817 & -1.318 & -0.238 \\
\hline RSC18 & 0 & 1.754 & -1.285 & -0.225 \\
\hline RSC19 & 0 & 1.72 & -1.275 & -0.219 \\
\hline $\mathrm{RSC} 20$ & 0 & 1.786 & -1.302 & -0.21 \\
\hline RSC21 & 0 & 1.783 & -1.312 & -0.18 \\
\hline RSC22 & 0 & 1.787 & -1.324 & -0.175 \\
\hline BI1 & 0 & 1.892 & -1.233 & -0.206 \\
\hline BI2 & 0 & 1.807 & -1.217 & -0.248 \\
\hline $\mathrm{BI} 3$ & 0 & 1.82 & -1.043 & -0.34 \\
\hline BI4 & 0 & 1.831 & -1.17 & -0.308 \\
\hline BI5 & 0 & 1.826 & -1.172 & -0.245 \\
\hline BI6 & 0 & 1.822 & -1.221 & -0.174 \\
\hline BI7 & 0 & 1.748 & -1.189 & -0.116 \\
\hline BI8 & 0 & 1.76 & -1.196 & -0.321 \\
\hline BI9 & 0 & 1.766 & -1.199 & -0.234 \\
\hline BI10 & 0 & 1.834 & -1.311 & -0.138 \\
\hline BI11 & 0 & 1.816 & -1.226 & 0.118 \\
\hline BI12 & 0 & 1.789 & -1.116 & -0.227 \\
\hline BI13 & 0 & 1.783 & -1.242 & -0.155 \\
\hline BI14 & 0 & 1.824 & -1.296 & -0.072 \\
\hline KM1 & 0 & 1.787 & -1.293 & -0.08 \\
\hline KM2 & 0 & 1.761 & -1.322 & -0.219 \\
\hline KM3 & 0 & 1.709 & -1.264 & -0.139 \\
\hline KM4 & 0 & 1.802 & -1.232 & -0.318 \\
\hline KM5 & 0 & 1.813 & -1.23 & -0.219 \\
\hline KM6 & 0 & 1.778 & -1.189 & -0.209 \\
\hline KM7 & 0 & 1.799 & -1.306 & -0.194 \\
\hline KM8 & 0 & 1.74 & -1.245 & -0.091 \\
\hline KM9 & 0 & 1.72 & -1.29 & -0.132 \\
\hline KM10 & 0 & 1.733 & -1.28 & -0.158 \\
\hline IS1 & 0 & 1.737 & -1.176 & -0.38 \\
\hline IS2 & 0 & 1.715 & -0.993 & -0.517 \\
\hline IS3 & 0 & 1.819 & -0.932 & -0.603 \\
\hline IS4 & 0 & 1.779 & -1.13 & -0.473 \\
\hline IS5 & 0 & 1.795 & -0.948 & -0.536 \\
\hline IS6 & 0 & 1.858 & -1.367 & -0.207 \\
\hline IS7 & 0 & 1.793 & -1.148 & -0.408 \\
\hline
\end{tabular}

Hence, from 369 questionnaires, 49 were rejected because they were incomplete and lastly 320 sets were formed suitable for statistical data analysis, which is about 64 percent of the total sample distribution. In this research, the reaction value was $80 \%$, which agrees with the prerequisite forced by Hair et al. (2010) who expressed that the base reaction value for a survey ought to be $50 \%$. The kurtosis and skewness of the placement can be estimated by the researcher to evaluate the standardization of the information. A piece of information is stated to have an ordinary circulation when its kurtosis and skewness rates are both zero, yet this seldom occurs (Hair et al., 2010). Thus, the core value for typical distribution is to receive components whose skewness rate is under 2 and the outright kurtosis rate is under 7 . The kurtosis and skewness rates 
of entire components in this research are inside the acceptable scope, as presented in Table 3. Based on Table 3, the data were analyzed using SPSS 22.0. The study design for the current research was evaluated through Structural Equation Modelling (SEM) procedures utilizing the Partial Least Square (PLS) technique.

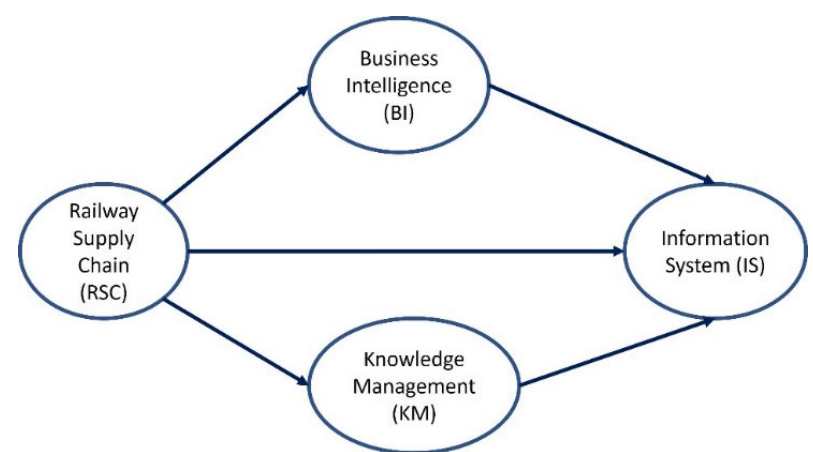

Fig. 4. Conceptual Model of Railway Supply Chain Excellence

The SmartPLS software version 3.2.8 was utilized as a programming device to convey SEM data analysis for quantifying and structural designs in this research. The evaluation of the quantifying model depends on reliability and validity gauges which were estimated through internal consistency, convergent validity values, indicator loading, and discriminant. Average Variance Extracted and(AVE) Composite Reliability (CR) rates for every latent variable were utilized to regulate convergent validity. The internal consistency was utilized to regulate the reliability of a scale utilized in a study tool. For this objective, Cronbach's alpha is normally utilized to quantify internal consistency which, in turn, regulates the reliability of a scale (Hair et al., 2010). The rates of 0.8 or 0.9 in advanced phases of the study show the internal consistency reliability of a quantifying design, whereas the rates underneath 0.6 demonstrate low reliability. The elevated Composite Reliability (CR) values indicate higher stability of components. For the current research, both Cronbach Alpha (CA) and Composite Reliability (CR) rates were significant than 0.6 and 0.7 as presented in Table 4 . These rates indicated an acceptable degree of construct reliability and, yet, revealed that the components utilized in the current research tool to address constructs possessed high internal consistency.

Table 4

Internal Consistency Measures

\begin{tabular}{ccc}
\hline Variables & Composite Reliability (CR) & Cronbach's Alpha (CA) \\
\hline RSC & 0.952 & 0.947 \\
BI & 0.948 & 0.941 \\
KM & 0.925 & 0.908 \\
IS & 0.914 & 0.887 \\
\hline
\end{tabular}

Indicator reliability was evaluated through outer loading or factor loading rates of every component. The indicator rate of 0.70 and above is considered acceptable and good. Indicator's rate between 0.40 and 0.70 ought to be examined for elimination if it rises the AVE and CR rates (Hair et al., 2010). A researcher ought to be cautious when removing an indicator as it possibly examines if the elimination of indicator improves the AVE and CR over the base edge rate, else it ought to be kept (Hair et al., 2010; Uma Sekaran, 2016). In this research, components with the outer loading rates of under $0.50-0.60$ were removed to advance evaluate the impact of removal on AVE and CR as featured in Table 5. Table 5 presents the indicator rates of the components between 0.50 and 0.60 and a directory of components removed depends on low indicator rates (outer loadings). The outer loading rates of components RSC9, RSC20, RSC21, IS6, and KM5 were found between 0.20 and 0.50 , thus AVE of the construct RSC9. RSC20 and RSC21 were discovered below a significant rate of 0.50 as stated in Table 5. Thus, these components were examined for one-by-one elimination to view the impact over the rate of AVE. Hence, the components with the small indicator rates (RSC9. RSC20, and RSC21) were removed which expanded the AVE rate over the threshold rate of 0.50.

Table 5

List of Eliminated Items

\begin{tabular}{ccccc}
\hline Items & Indicator Loading & AVE (Before Elimination) & Treatment & AVE (After Elimination) \\
\hline RSC9 & 0.356 & 0.444 & Removed & \\
RSC20 & 0.249 & 0.444 & Removed & \\
RSC21 & 0.285 & 0.444 & Removed & 0.512 \\
IS6 & 0.373 & 0.550 & Removed & 0.512 \\
KM5 & 0.276 & 0.527 & Removed & 0.639 \\
\hline
\end{tabular}

For the current research, the convergent validity was estimated by the rate of AVE as recommended by Uma Sekaran (2016). An AVE rate of 0.50 and beyond reveal satisfactory convergent validity. Table 6 curb the rates of AVE for the convergent validity of the constructs utilized in the current research. Every rate contented the base threshold rate $(0.50)$ of AVE, hence, it presented satisfactory convergent validity for the quantifying design of the current research. 


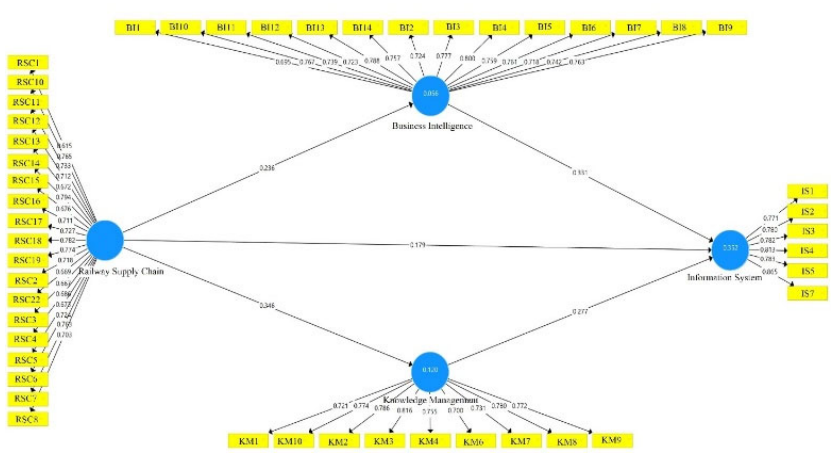

Fig. 5. Factor Loadings after Eliminations

Table 6

Average Variance Extracted (AVE) Values

\begin{tabular}{cc}
\hline Variables & Average Variance Extracted \\
\hline BI & 0.565 \\
RSC & 0.512 \\
IS & 0.639 \\
KM & 0.578 \\
\hline
\end{tabular}

To summarize the reliability and validity gauges, the evaluation affirmed that the quantifying design of the current research was legitimate and could be extra observed to evaluate the indicators of the structural model. Table 7 gives an outline of the rates of every item for the AVE, construct's factor loadings and CR rates.

Table 7

Summary of the assessment model

\begin{tabular}{|c|c|c|c|c|c|c|}
\hline Construct & Items & Factor loading & CA & CR & AVE & Discriminant Validity \\
\hline \multirow{14}{*}{ Business Intelligence (BI) } & BI1 & 0.695 & \multirow{14}{*}{0.941} & \multirow{14}{*}{0.948} & \multirow{14}{*}{0.565} & \multirow{14}{*}{ YES } \\
\hline & BI2 & 0.724 & & & & \\
\hline & BI3 & 0.777 & & & & \\
\hline & BI4 & 0.800 & & & & \\
\hline & BI5 & 0.759 & & & & \\
\hline & BI6 & 0.761 & & & & \\
\hline & BI7 & 0.718 & & & & \\
\hline & BI8 & 0.742 & & & & \\
\hline & BI9 & 0.763 & & & & \\
\hline & BI10 & 0.767 & & & & \\
\hline & BI11 & 0.739 & & & & \\
\hline & BI12 & 0.723 & & & & \\
\hline & BI13 & 0.788 & & & & \\
\hline & BI14 & 0.757 & & & & \\
\hline \multirow{19}{*}{ Railway Supply Chain (RSC) } & RSC1 & 0.615 & \multirow{19}{*}{0.947} & \multirow{19}{*}{0.952} & \multirow{19}{*}{0.512} & \multirow{19}{*}{ YES } \\
\hline & RSC2 & 0.718 & & & & \\
\hline & RSC3 & 0.667 & & & & \\
\hline & RSC4 & 0.686 & & & & \\
\hline & RSC5 & 0.673 & & & & \\
\hline & RSC6 & 0.724 & & & & \\
\hline & RSC7 & 0.763 & & & & \\
\hline & RSC8 & 0.703 & & & & \\
\hline & RSC10 & 0.765 & & & & \\
\hline & RSC11 & 0.733 & & & & \\
\hline & RSC12 & 0.712 & & & & \\
\hline & RSC13 & 0.672 & & & & \\
\hline & RSC14 & 0.794 & & & & \\
\hline & RSC15 & 0.676 & & & & \\
\hline & RSC16 & 0.711 & & & & \\
\hline & RSC17 & 0.727 & & & & \\
\hline & RSC18 & 0.782 & & & & \\
\hline & RSC19 & 0.774 & & & & \\
\hline & RSC22 & 0.669 & & & & \\
\hline \multirow{6}{*}{ Information System (IS) } & IS1 & 0.771 & \multirow{6}{*}{0.887} & \multirow{6}{*}{0.914} & \multirow{6}{*}{0.639} & \multirow{6}{*}{ YES } \\
\hline & IS2 & 0.780 & & & & \\
\hline & IS3 & 0.782 & & & & \\
\hline & IS4 & 0.813 & & & & \\
\hline & IS5 & 0.783 & & & & \\
\hline & IS7 & 0.865 & & & & \\
\hline
\end{tabular}


Table 7

Summary of the assessment model (Continued)

\begin{tabular}{|c|c|c|c|c|c|c|}
\hline Construct & Items & Factor loading & CA & CR & AVE & Discriminant Validity \\
\hline \multirow{9}{*}{ Knowledge Management (KM) } & KM1 & 0.721 & \multirow{9}{*}{0.908} & \multirow{9}{*}{0.925} & \multirow{9}{*}{0.578} & \multirow{9}{*}{ YES } \\
\hline & KM2 & 0.786 & & & & \\
\hline & KM3 & 0.816 & & & & \\
\hline & KM4 & 0.755 & & & & \\
\hline & КМ6 & 0.700 & & & & \\
\hline & KM7 & 0.731 & & & & \\
\hline & КМ8 & 0.780 & & & & \\
\hline & KM9 & 0.772 & & & & \\
\hline & KM10 & 0.774 & & & & \\
\hline
\end{tabular}

The issue of multicollinearity happens when there is a higher correlation among two or more independent variables of a study design. To gauge possible multicollinearity among the variables in this research, the Variance of Inflation Factors (VIF) rates were evaluated. Hair et al. (2010), stated that the VIF rates show the presence of collinearity level between independent variables depending on the tolerance of 0.20 or below and 10 or above VIF rates. The VIF rates estimated for the independent variables in the current research are detailed in Table 8.

Table 8

VIF Values

\begin{tabular}{|c|c|c|c|c|c|}
\hline Items & VIF & Items & VIF & Items & VIF \\
\hline BI1 & 2.027 & RSC5 & 2.038 & IS4 & 2.022 \\
\hline BI2 & 2.453 & RSC6 & 2.368 & IS5 & 1.940 \\
\hline BI3 & 2.474 & RSC7 & 2.640 & IS7 & 2.732 \\
\hline BI4 & 3.049 & RSC8 & 2.172 & KM1 & 1.794 \\
\hline BI5 & 2.501 & RSC10 & 2.834 & KM2 & 2.241 \\
\hline BI6 & 2.325 & RSC11 & 2.624 & KM3 & 2.811 \\
\hline BI7 & 2.149 & RSC12 & 2.293 & KM4 & 2.028 \\
\hline BI8 & 2.051 & RSC13 & 2.027 & KM6 & 2.055 \\
\hline BI9 & 2.721 & RSC14 & 2.662 & KM7 & 2.003 \\
\hline BI10 & 3.204 & RSC15 & 2.011 & KM8 & 2.235 \\
\hline BI11 & 2.502 & RSC16 & 2.331 & KM9 & 2.303 \\
\hline BI12 & 1.987 & RSC17 & 2.439 & KM10 & 2.567 \\
\hline BI13 & 3.201 & RSC18 & 2.778 & & \\
\hline BI14 & 2.844 & RSC19 & 2.788 & & \\
\hline RSC1 & 1.816 & RSC22 & 1.844 & & \\
\hline RSC2 & 2.494 & IS1 & 1.876 & & \\
\hline RSC3 & 2.267 & IS2 & 1.886 & & \\
\hline RSC4 & 2.522 & IS3 & 1.952 & & \\
\hline
\end{tabular}

Since every rate of VIF concerning the independent variables utilized in the current research is inside the significant curb $(0.20-10.00)$, hence, it can be asserted that there was no multicollinearity issue between the variables of the current research. The structural model of the research was further assessed through path coefficients. The rates of path coefficients were helpful to show the significance and strength of the relationship among the two variables. In SmartPLS, a method called "bootstrapping" was utilized to get rates for the paths among independent and dependent variables. Besides, p-values and tstatistics were evaluated to verify the importance of every path that existed among these variables. Hair et al. (2010) stated that the analyzed estimated statistical t-value is higher than the critical value, the coefficient is examined crucially at a particular confidence level. For the current research, a t-value of 0.95 was utilized at an important level of 0.05 . Hair et al. (2010) additionally clarified that a nonparametric statistical test called bootstrapping is conveyed by PLS-SEM to gauge the importance of assessed path coefficients. Besides, they expressed that the rates of coefficients are placed among +1 and -1 . Hence, the rates of path coefficients near to +1 demonstrated a significant relationship, while rates of coefficient near to -1 indicate weak relationships. The analyse estimated path coefficients, $t$-values, and $p$-values among variables in the current research are detailed in Table 9. Thus, based on the outcomes obtained for the current research, every variable was significant at an implication level of 0.05 .

Table 9

Path Coefficients

\begin{tabular}{|c|c|c|c|c|}
\hline Path & Path Coefficient & S. E & t-Value & p-Value \\
\hline $\mathrm{BI} \rightarrow \mathrm{IS}$ & 0.331 & 0.065 & 5.096 & 0.000 \\
\hline $\mathrm{RSC} \rightarrow \mathrm{BI}$ & 0.236 & 0.056 & 4.204 & 0.000 \\
\hline $\mathbf{R S C} \rightarrow$ IS & 0.179 & 0.061 & 2.925 & 0.003 \\
\hline $\mathbf{R S C} \rightarrow \mathbf{K M}$ & 0.346 & 0.057 & 6.106 & 0.000 \\
\hline $\mathbf{K M} \rightarrow \mathbf{I S}$ & 0.277 & 0.066 & 4.188 & 0.000 \\
\hline
\end{tabular}




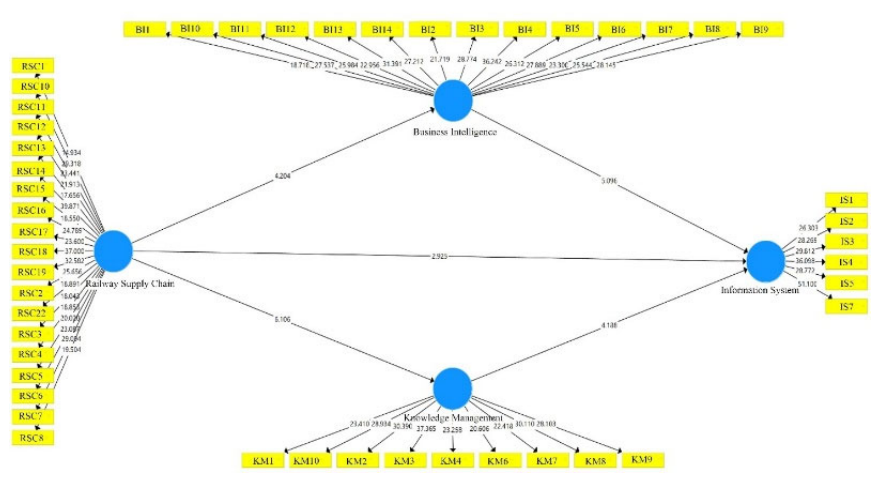

Fig. 6. Bootstrapping

Coefficient of determination $\left(R^{2}\right)$ rate is utilized to clarify the measure of variance in the dependent variable produced by the independent variables. The higher $R^{2}$ rates demonstrate the predictive capacity of the structural model. Yet, the stability of $R^{2}$ rates depend on the difficulty of the study design and classification of the domain (Hair et al., 2010). For instance, $R^{2}$ rates for endogenous latent variables are evaluated as 0.26 (substantial), 0.13 (moderate), 0.02 (weak) (Uma Sekaran, 2016). Besides, $R^{2}$ rates should be greater than or equal to 0.10 for the variance described of a specific endogenous construct to be considered satisfactory (Hair et al., 2010).

Table 10

Coefficient of Determination

\begin{tabular}{ccc}
\hline Variable & R Square & Result \\
\hline KM & 0.120 & Moderate \\
BI & 0.056 & Weak \\
IS & 0.352 & Substantial \\
\hline
\end{tabular}

The PLS algorithm analysis, shown in Table 10, $12.0 \%$ of the variance in KM was explained by RSC. Furthermore, $5.6 \%$ of the variance in BI was explained by the RSC. Also, 35.2\% of the variance in IS was explained by RSC, KM, and BI. Generally, outcomes represent that every $R^{2}$ rates surpassed the cut-off rate of 0.02 . The design then provided sufficient predictive capacity for the IS. The capability of the proposed study design of the current research was assessed through the rate of $f^{2}$ which clarified the impact size. Hair et al. (2010) stated that the rate of $f^{2}$ is estimated by an expansion in $R^{2}$ comparative to the extent of variance of the endogenous variable which stays unexplained. They extra clarified that rates of $f^{2}$ among the ranges of 0.02-0.14 are viewed as the weak impact, 0.15-0.34 moderate, and 0.35 and above a significant impact. For the current research, model fitness through $f^{2}$ was estimated and the rates acquired for every path are detailed in Table 11.

Table 11

$\mathbf{f}^{2}$ Values for Each Path

\begin{tabular}{lccc} 
& Path & Effect size & Results \\
\hline BI - IS & & 0.142 & Moderate \\
RSC - BI & 0.059 & Weak & Weak \\
RSC - IS & 0.043 & Moderate \\
RSC - KM & 0.136 & Weak \\
KM - IS & 0.093 & \\
\hline
\end{tabular}

The mediating role of $\mathrm{BI}$ and $\mathrm{KM}$ in the relationship between $\mathrm{RSC} \rightarrow \mathrm{BI} \rightarrow \mathrm{IS}$ and $\mathrm{RSC} \rightarrow \mathrm{KM} \rightarrow \mathrm{IS}$. As the mediating effect was determined through an indirect impact among dependent and independent variables through a mediating variable, the practical analysis in PLS was carried out in two-phase. The first phase was to verify the importance of indirect and direct impact rates through $\mathrm{p}$ values, path coefficients, and t-statistics. The following phase was to compute the VAF rate to set up the significance of mediation (no mediation, partial, or full).

Table 12

Direct and Indirect Paths $(\mathrm{RSC} \rightarrow \mathrm{BI} \rightarrow \mathrm{IS})$

\begin{tabular}{|c|c|c|c|c|c|}
\hline Path & Path coefficient & T Statistics & P Values & $2.5 \%$ & $97.5 \%$ \\
\hline $\mathrm{BI} \rightarrow \mathrm{IS}$ & 0.421 & 7.499 & 0.000 & 0.309 & 0.532 \\
\hline $\mathrm{RSC} \rightarrow \mathrm{BI}$ & 0.237 & 4.276 & 0.000 & 0.137 & 0.352 \\
\hline RSC $\rightarrow$ IS & 0.254 & 4.716 & 0.000 & 0.153 & 0.363 \\
\hline $\begin{array}{c}\text { RSC } \rightarrow \text { BI } \rightarrow \text { IS } \\
\text { (Indirect Effect) }\end{array}$ & 0.100 & 3.565 & 0.000 & 0.054 & 0.164 \\
\hline $\begin{array}{c}\mathbf{R S C} \rightarrow \text { IS } \\
\text { (Total Effect) }\end{array}$ & 0.354 & 6.912 & 0.000 & 0.264 & 0.463 \\
\hline
\end{tabular}


For this reason, VAF was assessed by isolating an indirect impact over the total impact. The findings detailed in Table 12 were acquired by implementing the bootstrapping procedure in PLS-SEM. The findings detailed in Table 12, show the coefficient value of the total direct impact $(0.354)$ among $\mathrm{RSC} \rightarrow \mathrm{IS}$ was significant $(\mathrm{t}=6.912, \mathrm{p}=0.000)$. The indirect path $(\mathrm{RSC} \rightarrow \mathrm{BI} \rightarrow \mathrm{IS})$ was estimated as 0.100 and established significance $(\mathrm{t}=3.565, \mathrm{p}$-value $=0.000)$. However, the direct impacts among $(\mathrm{RSC} \rightarrow \mathrm{IS}, \mathrm{RSC} \rightarrow \mathrm{BI}$ and $\mathrm{BI} \rightarrow \mathrm{IS})$ were significant as detailed in Table 12.

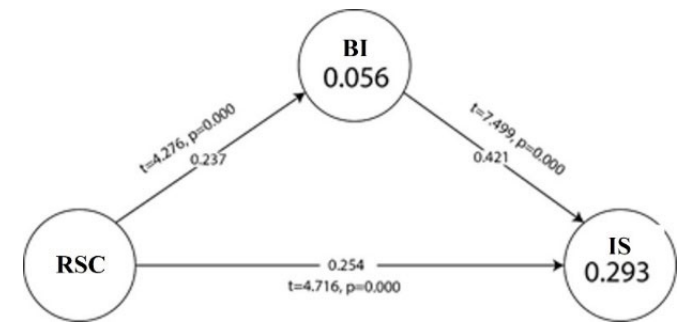

Fig. 7. Path Coefficients (RSC $\rightarrow \mathrm{BI} \rightarrow \mathrm{IS})$

Hair et al. (2010) stated that upper and lower confidence intervals should not curb any zero rates. Hence, the upper and lower rates of the bootstrap confidence interval should likewise be accounted for with the importance of the indicators which is viewed as more insight than simply reporting the meaning of the components. Besides, detailing upper and lower confidence interval values gives more data concerning the strength of the coefficient gauges. As revealed in Table 12 and displayed in Figure 7, the lower confidence value of the indirect impact was 0.054 and the upper confidence level rate was 0.164 . Bootstrapping findings affirmed the stability and significance of the mediating impact of BI among RSC and IS because there was no rate of 0 revealed by the upper and lower confidence intervals. Thus the rates detailed in Table 12, the indirect impact $(\mathrm{RSC} \rightarrow \mathrm{BI} \rightarrow \mathrm{IS}$ ) was 0.100 and the total impact $(\mathrm{RSC} \rightarrow \mathrm{IS}$ ) was 0.354 . Therefore, VAF rate was assessed as 0.282 of $28.2 \%$ (indirect effect/total effect $=0.100 / 0.354$ ). BI partially mediated between RSC and IS because the VAF rate was between $20 \%$ and $80 \%$. The rates detailed in Table 12 and the VAF rate showed the indicators of the proposed mediation part and explained the context for partial mediation. The findings presented in Table 13 were acquired by implementing the bootstrapping procedure in PLS-SEM. The findings detailed in Table 13, the coefficient value of the total direct impact $(0.354)$ among $\mathrm{RSC} \rightarrow \mathrm{IS}$ was significant $(\mathrm{t}=6.717, \mathrm{p}=0.000)$. The indirect path $(\mathrm{RSC} \rightarrow \mathrm{KM} \rightarrow \mathrm{IS})$ was estimated as 0.137 and initiated significance $(\mathrm{t}=4.195, \mathrm{p}$-value $=0.000)$. Yet, the direct impact among $(\mathrm{RSC} \rightarrow \mathrm{IS}, \mathrm{RSC} \rightarrow \mathrm{KM}$ and $\mathrm{KM} \rightarrow \mathrm{IS})$ was significant as detailed in Table 13.

Table 13

Direct and Indirect Paths (RSC $\rightarrow \mathrm{KM} \rightarrow \mathrm{IS}$ )

\begin{tabular}{|c|c|c|c|c|c|}
\hline Path & Path coefficient & T Statistics & P Values & $2.5 \%$ & $97.5 \%$ \\
\hline $\mathbf{K M} \rightarrow$ IS & 0.394 & 6.664 & 0.000 & 0.280 & 0.510 \\
\hline $\mathrm{RSC} \rightarrow \mathrm{KM}$ & 0.347 & 6.179 & 0.000 & 0.245 & 0.464 \\
\hline $\mathrm{RSC} \rightarrow \mathrm{IS}$ & 0.217 & 3.514 & 0.000 & 0.098 & 0.340 \\
\hline $\begin{array}{l}\mathbf{R S C} \rightarrow \mathbf{K M} \rightarrow \mathbf{I S} \\
\text { (Indirect Effect) }\end{array}$ & 0.137 & 4.195 & 0.000 & 0.084 & 0.211 \\
\hline $\begin{array}{c}\text { RSC } \rightarrow \text { IS } \\
(\text { Total Effect) }\end{array}$ & 0.354 & 6.717 & 0.000 & 0.257 & 0.463 \\
\hline
\end{tabular}

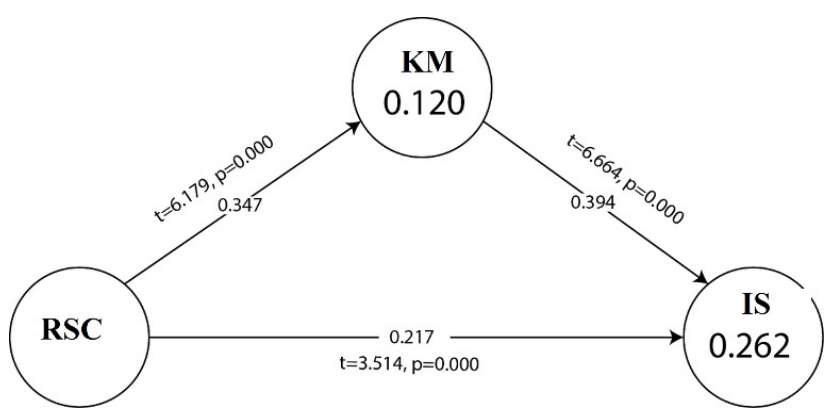

Fig. 8. Path Coefficients (RSC $\rightarrow \mathrm{KM} \rightarrow \mathrm{IS}$ )

As detailed in Table 13 and displayed in Figure 8, the lower confidence rate of the indirect impact was 0.084 and the upper confidence level rate was 0.211 . Bootstrapping findings affirmed the stability and significance of the mediating impact of $\mathrm{KM}$ among RSC and IS because there was no rate of 0 announced by the upper and lower confidence intervals. Moreover, the rates detailed in Table 13, the indirect impact $(\mathrm{RSC} \rightarrow \mathrm{KM} \rightarrow \mathrm{IS}$ ) was 0.137 and the total impact $(\mathrm{RSC} \rightarrow \mathrm{IS})$ was 0.354 . Thus, VAF rate was assessed as 0.387 of $38.7 \%$ (indirect effect/total effect $=0.137 / 0.354$ ). KM partially mediated among RSC and IS because the VAF rate was between $20 \%$ and $80 \%$ was assumed. The rates detailed in Table 13 and the VAF rate displayed the importance of the suggested mediation part and advocated the state for partial mediation. 


\section{Conclusions}

The railway supply chain is well organized in Malaysia and possesses excessive governmental initiation which generates outcomes for the Malaysian economy. Therefore, there is a need for railway supply chain excellence to manage efficiently and effectively towards the fast progress of knowledge in informatics and communications technologies for the strategic proposition. They need to further strengthen their capacity for supply chain performance with the intelligence and measures the execution of railway suppliers for performance action and directions. Moreover, we need to focus on the railway supply chain relationship towards information systems for future knowledge development plus intelligence in the problem-solving mechanism. Yet with determination and the right knowledge of supply chain management can drive digital learning skills towards knowledge-driven of $21^{\text {st }}$-century in virtual-based decision making. Moreover, it requires to include a significant supply chain direction into their strategic designing action to obtain a competitive edge. Thus, in some cases, the railway supply chain has executed the planning, but nothing improves because they have picked some unacceptable or insignificant measurements that won't bring any improvement for the supply chain management. Therefore, all these different approaches lead to the same end that indicates strategic planning as a key for railway supply chain excellence.

\section{Acknowledgments}

The researchers would love to thank the unknown reviewers and the editor for their comments to structure the manuscript. The researchers also wish to precise feelings toward Universiti Teknikal Malaysia Melaka (UTeM) for the UTeM Zamalah Scheme for sponsorship and supporting this analysis work.

\section{References}

Cagnin, F., Oliveira, M. C., Simon, A. T., Helleno, A. L., \& Vendramini, M. P. (2016). Proposal of a method for selecting suppliers considering risk management. International Journal of Quality \& Reliability Management, 33(4), 488-498. https://doi.org/10.1108/IJQRM-11-2014-0172

Chourides, P., Longbottom, D., \& Murphy, W. (2003). Excellence in knowledge management: an empirical study to identify critical factors and performance measures. Measuring Business Excellence, 7(2), 29-45. https://doi.org/10.1108/13683040310477977

Comuzzi, M., \& Parhizkar, M. (2017). A methodology for enterprise systems post-implementation change management. Industrial Management \& Data Systems, 117(10), 2241-2262. https://doi.org/10.1108/IMDS-11-2016-0506

Emery, J. C., \& Morton, M. S. S. (1972). Management Decision Systems: Computer-Based Support for Decision Making. Administrative Science Quarterly, 17(1), 142. https://doi.org/10.2307/2392104

Hair, Black, W. C., Babin, B. J., \& Anderson, R. E. (2010). Multivariate data analysis :global perspective.

Halvorson, H. (2012). What Scientific Theories Could Not Be*. Philosophy of Science, 79(2), $183-206$. https://doi.org/10.1086/664745

Jayakrishnan, M., Mohamad, A. K., \& Yusof, M. M. (2020a). Business Architecture Model in Strategic Information System Management for Effective Railway Supply Chain Perspective. International Journal of Engineering Research and Technology., 13(11), 3927-3933.

Jayakrishnan, M., Mohamad, A. K., \& Yusof, M. M. (2020b). Digitalization Railway Supply Chain 4.0: Enterprise Architecture Perspective. International Journal of Advanced Trends in Computer Science and Engineering, 9(5), 90569063. https://doi.org/10.30534/ijatcse/2020/310952020

Jayakrishnan, M., Mohamad, A. K., \& Yusof, M. M. (2020c). Information System for Integrative and Dynamic Railway Supply Chain Management. International Journal of Advanced Trends in Computer Science and Engineering, 9(2), 21592167. https://doi.org/10.30534/ijatcse/2020/191922020

Jayakrishnan, M., Mohamad, A. K., \& Yusof, M. M. (2020d). Strategic Information System for Decision Making in Railway Supply Chain Management. International Journal of Advanced Trends in Computer Science and Engineering, 9(3), 39883994. https://doi.org/10.30534/ijatcse/2020/223932020

Jayakrishnan, M., Mohamad, A. K., \& Yusof, M. M. (2021). Developing railway supplier selection excellence using business intelligence knowledge management framework. International Review of Applied Sciences and Engineering, 12(3), 257268. https://doi.org/10.1556/1848.2021.00267

Malhotra, N. (2007). Marketing Research : An Applied Orientation. Pearson.

Martin, D., Rooksby, J., Rouncefield, M., \& Sommerville, I. (2007). "Good” Organisational Reasons for "Bad” Software Testing: An Ethnographic Study of Testing in a Small Software Company. In 29th International Conference on Software Engineering (ICSE'07) (pp. 602-611). IEEE. https://doi.org/10.1109/ICSE.2007.1

MIGHT. (2018). Future Rail 2030 - Development of National Rail Industry Roadmap. Malaysian Industry Government Group for High Technology, 9(5), 1-29.

Ming, T., Teng, W., \& Jodaki, S. (2020). A model to investigate the effect of information technology and information systems on the ease of managers' decision-making. Kybernetes, ahead-of-p(ahead-of-print). https://doi.org/10.1108/K-10-20190712 
Odolinski, K. and Boysen, H. E. (2019). Railway line capacity utilisation and its impact on maintenance costs. Ournal of Rail Transport Planning \& Management, 9(1), 22-33.

Petrillo, A., Felice, F. De, Cioffi, R., \& Zomparelli, F. (2018). Fourth Industrial Revolution: Current Practices, Challenges, and Opportunities. In Digital Transformation in Smart Manufacturing (pp. 1-20). InTech. https://doi.org/10.5772/intechopen.72304

Safa, M., Shahi, A., Haas, C. T., \& Hipel, K. W. (2014). Supplier selection process in an integrated construction materials management model. Automation in Construction, 48, 64-73. https://doi.org/10.1016/j.autcon.2014.08.008

Santis, R. B. de, Golliat, L., \& Aguiar, E. P. de. (2017). Multi-criteria supplier selection using fuzzy analytic hierarchy process: case study from a Brazilian railway operator. Brazilian Journal of Operations \& Production Management, 14(3), 428. https://doi.org/10.14488/BJOPM.2017.v14.n3.a15

Saunders, M., Lewis, P., \& Thornhill, A. (2009). for Business Students Fi Fth Edition.

Sousa, F. J. (2010). Chapter 9 Metatheories in research: positivism, postmodernism, and critical realism. Advances in Business Marketing and Purchasing (Vol. 16). Elsevier. https://doi.org/10.1108/S1069-0964(2010)0000016012

Uma Sekaran. (2016). Research Methods For Business. In Intergovernmental Panel on Climate Change (Ed.), Climate Change 2013 - The Physical Science Basis (Vol. 65, pp. 1-30). Cambridge: Cambridge University Press. https://doi.org/10.1017/CBO9781107415324.004

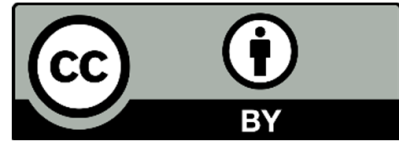

(C) 2022 by the authors; licensee Growing Science, Canada. This is an open access article distributed under the terms and conditions of the Creative Commons Attribution (CCBY) license (http://creativecommons.org/licenses/by/4.0/). 